\title{
Analysis of Exposure To Radon in Bulgarian Rehabilitation Hospitals
}

\section{Kremena Georgieva Ivanova ( $\nabla$ k.ivanova@ncrrp.org )}

National Center of Radiobiology and Radiation Protection: Nacionalen cent'r po radiobiologia i radiacionna zasita https://orcid.org/0000-0003-0731-4259

\section{Desislava Djuvnakova}

National Center of Radiobiology and Radiation Protection: Nacionalen cent'r po radiobiologia i radiacionna zasita

\section{Zdenka Stojanovska}

Goce Delchev University Shtip: Goce Delcev University

\section{Jana Djounova}

National Center of Radiobiology and Radiation Protection: Nacionalen cent'r po radiobiologia i radiacionna zasita

\section{Bistra Kunovska}

National Center of Radiobiology and Radiation Protection: Nacionalen cent'r po radiobiologia i radiacionna zasita

\section{Nina Chobanova}

National Center of Radiobiology and Radiation Protection: Nacionalen cent'r po radiobiologia i radiacionna zasita

\section{Research Article}

Keywords: mineral water, radon, rehabilitation hospital, track detector, radiation dose

Posted Date: June 18th, 2021

DOl: https://doi.org/10.21203/rs.3.rs-550240/v1

License: (a) This work is licensed under a Creative Commons Attribution 4.0 International License. Read Full License 
Analysis of exposure to radon in Bulgarian rehabilitation hospitals

\author{
Kremena Ivanova $^{1 a}$, Desislava Djuvnakova ${ }^{1}, Z_{\text {Zdenka Stojanovska }}{ }^{2}$, Jana Djounova ${ }^{1}$, Bistra \\ Kunovska $^{1}$, Nina Chobanova ${ }^{1}$ \\ ${ }^{1}$ National Centre of Radiobiology and Radiation Protection, 3 Sv. Georgi Sofiyski st., 1606 \\ Sofia, Bulgaria \\ ${ }^{2}$ Faculty of Medical Sciences, Goce Delcev University of Stip, 10-A Krste Misirkov st., 2000 \\ Stip, Republic of North Macedonia \\ ${ }^{a}$ Corresponding author: Tel.: +359878124368 ; fax: +35928621059 \\ E-mail address: k.ivanova@ncrrp.org and kivanova1968@gmail.com (K. Ivanova)
}

\begin{abstract}
Mineral springs are used in spa resorts throughout the world. Radon is a natural radioactive source, which can dissolve, accumulate, and be transported by water. This study investigates the radon concentration in air and water in 12 Bulgarian rehabilitation hospitals and presents the assessment of the exposure to radon in them. The measurements were performed at 401 premises within 21 buildings, using two types of passive detectors for a dry and wet environment that were exposed from February, 2019 to June, 2019. The radon concentration varied from 19 to $2550 \mathrm{~Bq} / \mathrm{m}^{3}$ with an arithmetic mean and a standard deviation of $102 \mathrm{~Bq} / \mathrm{m}^{3}$ and $191 \mathrm{~Bq} / \mathrm{m}^{3}$, respectively. The hypothesis that in hospitals the source of radon, besides soil under the buildings, is also the mineral water that is used for treatment, was tested. Thermal water samples were procured sequentially from a spring and baths to analyse the reduction of radon concentration in them till reaching the premises. The results show that the concentration of radon decreased by approximately $50 \%$. Further, the correlation analysis applied to the data proved the relation of the levels of indoor radon in the treatment rooms with those in the water. Mineral water used in rehabilitation hospitals have radon transfer coefficients ranging from $4.5 \cdot 10^{-4}$ to $8.4 \cdot 10^{-3}$. In addition, an analysis of the exposure of patients and workers to radon in rehabilitation hospitals based on the indoor radon levels and period of exposure was performed.
\end{abstract}

Key words: mineral water; radon; rehabilitation hospital; track detector; radiation dose

Acknowledgements This work is supported by the Bulgarian National Science Fund of the Ministry of Education and Science (Project КП-06-H23-1/2018 г). The authors express their gratitude to the Management of Specialized Rehabilitation Hospitals for the support of the survey.

1. IntroductionRadon $\left({ }^{222} \mathrm{Rn}\right)$ is a natural radioactive gas formed from the radioactive decay of ${ }^{226} \mathrm{Ra}$ to short-lived radioactive products. Radon and its decay products are recognized as the most significant natural source of human exposure (UNSCEAR, 2006), and its inhalation can cause lung cancer (WHO, 2009). To identify the radon sources, and explain the factors that affect radon dynamics in an indoor environment, numerous measurements of radon have been performed in various homes and workplaces around the world.It is well known that in most of the cases, the main source of indoor radon is the radon that is generated in the underlying rock and soil of the buildings, which is transported indoors because of concentrations and pressure difference flows. In addition, the radon gas can dissolve and accumulate in water from underground sources, such as wells or mineral springs, where the water, which comes from deep springs, can contain high radon concentration because of leaching of rocks, making it an additional source of indoor radon. Further, rehabilitation centres use mineral water for therapy, which can have higher levels of radon. Furthermore, concentrations of radon $\left({ }^{222} \mathrm{Rn}\right)$ in thermal waters can vary from $10 \mathrm{~Bq} / \mathrm{l}$ to above $1000 \mathrm{~Bq} / \mathrm{l}$ (Szerbin, 1996; Vogiannis et al., 2004; Manic et al., 2006; Nikolopoulos et al., 2010). The balneotherapy process using thermal water contributes to radon release into the indoor air and because of large volume of water used, the concentrations could reach a high value. Considering the health effects of radon, the professional staff could be exposed to a significant amount of radon. In literature, the annual effective doses reported for such workers have varied from several units to tens mSv per year (Radolić et al., 2005; Zunic et al., 2006). 